\title{
Comparison of alternative harvesting systems for selective thinning in a Mediterranean pine afforestation (Pinus halepensis Mill.) for bioenergy
}

use

\author{
Victoria Lerma-Arce ${ }^{(1)}$, \\ Jose-Vicente Oliver-Villanueva ${ }^{(1)}$, \\ Guillem Segura-Orenga ${ }^{(2)}$, \\ Javier F Urchueguia-Schölzel ${ }^{(1)}$
}

Due to a continuous abandonment of marginal agricultural land, Mediterranean pine forests are growing both in biomass stock and area but remain mainly unmanaged. Pinus halepensis is one of the main pioneer species with strong expansion throughout the Mediterranean basin. In mature forests and pole stands, selective thinnings aimed to eliminate dominated and dead trees are necessary to improve the resilience and persistence of these forest ecosystems. Bioenergy market provides an opportunity to mobilise this woody material, helping to prevent and reduce wildfires in a context of climate change and energy transition. Despite the existing expertise on wood harvesting, there is a lack of practical knowledge about cost-effective methods for bioenergy use of selective thinnings in such forests. The objective of this study was to compare thinning harvesting methods in representative 63-year-old Pinus halepensis afforestation in pole stage for bioenergy uses, following the silvicultural treatments defined in the Spanish forest management plan. Time studies were performed over six representative plots in Navalón (Spain). Treatments included three plots with the traditional stem wood method combined with the logging of forest residues (integrated system), and three plots with the whole tree chipping (whole tree system). Time, productivity and fuel consumption were recorded for both systems. A woodchip quality assessment of each assortment was performed in the laboratory according to European standards. The results obtained demonstrated that time consumption and productivity were similar between the integrated harvesting system and the whole tree system. Regarding the total energy balance, it should be noted that both systems produce woodchips that contain over ten times more energy than that required to mobilise and process the obtained biomass. Fuel consumption, costs and degree of damage were slightly higher in the whole tree system due to the more intensive forwarding operation. The two assortments of woodchips in the integrated system had a higher (chipped log material) and lower quality (chipped crown material) than whole tree woodchips. In conclusion, integrated harvesting is a better option to diminish fuel consumption, cost and environmental impact, and also to obtain better quality woodchips for the production of added value biofuels (pellets).

(1) Universitat Politècnica de València, Institute for Information and Communication Technologies - ITACA, Research Group on ICT vs. Climate Change, Camí de Vera s/n, 46022 València (Spain); (2) AIDIMME - Wood\&Metal Technology Institute, Benjamin Franklin 13, 46180 Paterna (Spain)

\section{@ Victoria Lerma-Arce (vlerma@upv.es)}

Received: Aug 27, 2020 - Accepted: Aug 10, 2021

Citation: Lerma-Arce V, Oliver-Villanueva JV, Segura-Orenga G, Urchueguia-Schölzel JF (2021). Comparison of alternative harvesting systems for selective thinning in a Mediterranean pine afforestation (Pinus halepensis Mill.) for bioenergy use. iForest 14: 465-472. doi: 10.3832/ifor3636-014 [online 2021-1016]

Communicated by: Rodolfo Picchio

Keywords: Pinus halepensis, Selective Thinnings, Bioenergy Harvesting, Logging Residues, Woodchips, Net Energy Efficiency, Whole-tree Biomass

\section{Introduction}

There has been a substantial expansion of Aleppo pine (Pinus halepensis Mill.) from plantations to abandoned agricultural land and natural sites dominated by shrubland across the Mediterranean basin, especially in the western area (Maestre \& Cortina 2004). After large public reforestation programmes conducted in Spain between 1950 and 1970, extensive areas were reforested in the Mediterranean regions with pine species, mainly with Pinus halepensis, with the goal of producing quality timber and restoring semi-arid and even arid deforested soils (Maestre \& Cortina 2004). Pinus halepensis is well adapted from semiarid to sub humid conditions across the Mediterranean basin (Jaouadi et al. 2019). Both forest growth and production (Sghaier \& Ammari 2012) and natural regenera- tion (Goubitz et al. 2002) increase with the potential of the forest site, the bioclimatic stage, and soil fertility. Pinus halepensis forests is managed to produce even-aged stands including selective thinnings (Vennetier et al. 2010). Navarro et al. (2010) showed a positive and significant response of Pinus halepensis trees in thinned stands compared to controls treatments, in spite of periods of low-rainfall and plague stress. These tree responses along with structural changes to afforestation affects forest management in the context of global change in the Mediterranean region where increases in temperature and reductions and irregularity in precipitation are forecasted, with the consequent rise in wildfire risks (Pecchi et al. 2019). Moreover, natural regeneration in Pinus halepensis stands is normally achieved by clear-cutting small ar- 
eas in mature stands (Moya et al. 2008) in periods of 10 to 20 years or even after wildfires (Barbati et al. 2010). Lavi et al. (2005) showed that the natural dispersal of seeds is weak in Pinus halepensis stands. Consequently, spreading branches bearing cones from thinning or clearcutting increases the quantity of seeds dispersed. Furthermore, tillage associated with high cover density facilitates the establishment of seeds (Jaouadi et al. 2019).

Regarding the state of forests in the Mediterranean basin, there is a general lack of forest management of Pinus halepensis stands, which has been confirmed in recent studies (PROFORBIOMED 2014, ForBioEnergy 2019, Jaouadi et al. 2019). Currently, less than $10 \%$ of the public forests have an active management plan in Eastern Spain (Lerma-Arce 2015). Moreover, the investment level in private forestry is very low due to the low economical revenues achieved by current forest projects. Therefore, in general, forest stands in large Mediterranean regions lack of any silvicultural treatments (PATFOR 2012). High tree density, strong declining of the radial tree growth and continuous accumulation of dried biomass result in a low value and quite vulnerable stock with a high risk of wildfires (PROFORBIOMED 2014).

Nevertheless, rising bioenergy markets in southern Europe offer an opportunity to mobilise untapped woody biomass helping to prevent and reduce wildfires in a context of climate change and energy transition (Balboa et al. 2003). Woody biomass for bioenergy is the main source of renewable energy in Europe, with a share of almost 60\%. The heating and cooling sector is the largest consumer, using about $75 \%$ of all bioenergy (Scarlat et al. 2019). Bioenergy contributes to EU's energy security, as more than $95 \%$ of the demand is met with domestically produced biomass (European Commission 2020). Forestry is the main source of biomass for energy (logging residues, wood-processing residues, fuelwood, etc.) and wood pellets (mainly for heating) have become an important energy carrier (Scarlat et al. 2019). The forestbased biomass sector is well developed in central and northern Europe (Proskurina et al. 2016), featured by local and regional

Tab. 1 - Forest inventory data of the representative forest of the 60-years-old reforestation of Pinus halepensis. (SE): standard error of the mean.

\begin{tabular}{lr}
\hline Parameter & \multicolumn{1}{c}{ Value } \\
\hline Average DBH $(\mathrm{cm}) \pm \mathrm{SE}$ & $20.05 \pm 1.86$ \\
\hline Basal area $\left(\mathrm{G}, \mathrm{m}^{2} \mathrm{ha}^{-1}\right)$ & 24.94 \\
\hline Density $($ trees ha-1 $)$ & 718 \\
\hline Volume $\left(\mathrm{m}^{3} \mathrm{ha}^{-1}\right)$ & 106.5 \\
\hline $\begin{array}{l}\text { Average tree height } \\
\left(\mathrm{H}_{0}, \mathrm{~m}\right) \pm \mathrm{SE}\end{array}$ & $14.2 \pm 0.99$ \\
\hline Unit volume $\left(\mathrm{m}^{3}\right.$ tree $\left.^{-1}\right)$ & 0.14 \\
\hline
\end{tabular}

supply chains (Acuna et al. 2019), conventional advanced forest operations (Spinelli et al. 2019) and logistics (Joelsson et al. 2016, Triplat \& Krajnc 2020) in forests and short rotation coppices (Schweier et al. 2015). In contrast, southern Europe faces important challenges such as economic and regular restrictions, and a lack of adequate equipment and qualified personal for harvesting and processing, in both western (ForBioEnergy 2019) and eastern Mediterranean countries (Rauch et al. 2015). Most forest development programmes in the Mediterranean basin aim at increasing the energy valorisation of residual forest biomass as a strategy to mobilise higher value-added wood products, prevent large wildfires and provide local employment in rural areas (PATFOR 2012).

On the other hand, forest companies supplying roundwood primarily for sawmills and wood-based panel industries have limited experience in producing chips for bioenergy (BEST4VARIOUSE 2012). Little research in biomass harvesting adapted to Mediterranean pine forest conditions has been performed and published, which has translated into a lack of knowledge by forest owners and harvesting companies about real market prices as well as harvesting and logistics costs (Lerma-Arce 2015). Therefore, there is a need for expanded knowledge of advanced harvesting technologies to produce woodchips in these increasingly growing forest areas (PATFOR 2012, PROFORBIOMED 2014, ForBioEnergy 2019).

The general objective of this study was to compare the integrated woody-biomass (IS) and whole tree harvesting (WTS) systems in representative forests of Pinus halepensis in pole stage for bioenergy uses. To achieve this, the research had the following specific objectives: (i) to analyse and compare time, biomass yield and fuel consumption; (ii) to calculate and compare productivity of both systems; (iii) to calculate and compare total harvesting costs; (iv) to assess the quality of the woodchips produced; and (v) to evaluate the net energy efficiency of each bioenergy system, from the forest to the bioenergy plant.

\section{Materials and methods}

\section{Selection of representative plots}

A representative 63-year-old afforested stand of Pinus halepensis established without any previous silvicultural treatment was selected in the forest district Vo74 Navalón, Spain $\left(38^{\circ} 55^{\prime} 10^{\prime \prime} \mathrm{N}, 00^{\circ} 55^{\prime} 29^{\prime \prime}\right.$ $W)$. Six plots of 0.25 ha $(50 \times 50 \mathrm{~m})$ each were selected by random sampling from a homogeneous forest stand of 4 ha. The average terrain slope was $10 \%$. Descriptive forest data is shown in Tab. 1.

In order to assure homogeneity among forest plots, the normality of the distribution of DBH and volume per tree were tested and subsequently, the analysis of variance (ANOVA) was applied.

\section{Harvesting methods}

A low selective thinning was carried out with the same harvesting intensity (35\% of the standing trees) over the six plots. After testing of the harvesting equipment by local forest contractors, the following harvesting systems were selected: (a) whole tree system (WTS), including full-tree chipping; (b) integrated harvesting system (IS) as traditional stem wood system (by delimbing tree stems) combined with the extraction of logging residues (tops and branches) in separated loads, also including separated chipping of stem and residues.

Each selected system had three test plots assigned. A single operator performed all felling operations using a $2.8 \mathrm{~kW}$ chainsaw (model MS-261 ${ }^{\oplus}$, Stihl AG \& Co., Waiblingen, Germany). Biomass (both stems and residues separately in the case of IS system) was forwarded by a single operator driving an $88 \mathrm{CV}$ forwarder (model $\mathrm{A} 83^{\circledR}$, Valtra-Hitraf, Pontevedra, Spain); forest plots were located at a distance of $800 \mathrm{~m}$ from the forest road and with an altitudinal difference of $40 \mathrm{~m}$ between the forest plots and the loading area. Another operator comminuted the biomass collected with a semi-mobile chipper Stark SH- $4585^{\oplus}$ ( $385 \mathrm{CV}$ ) connected to a truck; the biomass was separated into three different piles: woodchips from logs and woodchips from residues obtained from IS, and woodchips from whole-trees obtained from WTS (Fig. 1). The chipping process was carried out at the roadside three weeks later; this allow air drying the biomass to obtain chips with a lower moisture content and less fine material (especially needles and cones).

Finally, multi-lift trucks were loaded with the woodchips, which were transported to a bioenergy plant (40 km away) for final drying and transformation into thermal energy.

The same contractor performed the harvesting in all the plots (using the same machinery and operators) to avoid distortions on the field tests.

\section{Time analysis}

The time analysis followed the methodology developed by Magagnotti \& Spinelli (2012), corresponding to an observational study at plot level. The time of the working components (felling, extraction, chipping) in each plot was recorded manually with a stopwatch through a continuous-time measurement (Ambrosio \& Tolosana 2007). In the felling phase, the time for felling, delimbing and cross-cutting of the crown was recorded, together with fuel recharging and chainsaw sharping time. The extraction phase was measured at a cycle level by recording the time consumed by the forwarder during loading, transport to the loading area, unloading and unloaded transport back to the plot. The chipping phase was measured at continuous time for each biomass pile. Mechanical, personal and organizational delay times were count- 
ed and registered. When no delays occurred, $35 \%$ of delay time over net time was assumed for gross calculations of forwarding times (Magagnotti \& Spinelli 2012). Only one experimental plot was harvested at a time to ensure proper monitoring and recording of the time components. Furthermore, the same operators worked all plots to avoid variability due to experience and working conditions.

\section{Analysis of biomass yield and fuel consumption}

The number of felled trees per plot was counted while biomass volume and weight at $45 \%$ moisture content were estimated per plot and per hectare by measuring the height and $\mathrm{DBH}$ of each tree and applying the allometric equations for Pinus halepensis proposed by Montero et al. (2005). During the felling phase, fuel and oil recharges (number and amount) were recorded. The forest contractor provided the fuel consumption data for the forwarder and chipper.

A t-test $(\alpha=0.05)$ was applied to determine if the means of the two sets of data, in this case, biomass yield and fuel consumption, from WTS and IS were significantly different from each other.

\section{Calculation of productivity}

The productivity of each harvesting phase (felling, forwarding, and chipping; in $\mathrm{t} \mathrm{h}^{-1}$ ) was calculated following the methodology described by Magagnotti \& Spinelli (2012) taking real productive machine hours from field time records. T-tests ( $\alpha=0.05$ ) were applied to the productivity of each harvesting process to determine whether the means of the two datasets (WTS and IS) were statistically significantly different from each other.

\section{Biomass quality assessment}

Woodchip samples of $5 \mathrm{~kg}$ each one from the three different piles were separated and sent to the biomass laboratory of AIDIMME (Paterna, Spain). Here, the following equipment was used to analyse biomass quality: mechanical vibration

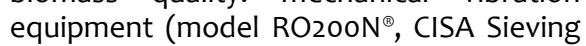
Technologies, Barcelona, Spain); drying oven (UFE $700^{\oplus}$, Memmert Gmbh, Schwabach, Germany); precision balance (ED1245 ${ }^{\circledR}$, Sartorius AG, Göttingen, Germany); muffle furnace (AAF1100 ${ }^{\circledR}$, Carbolite Gero Ltd., Hope, UK); $1 \mathrm{~kW}$ particle mill $\left(\mathrm{MF}^{\circ}{ }^{\circledR}\right.$, IKAWerke, Staufen, Germany); calorimetric pump (PARR $1351^{\oplus}$, Parr Instruments Co., Moline, IL, USA).

The methodology proposed by the European standard EN-14961 (2011) was followed for the analysis of woodchips quality. This standard details the procedures for the characterization of woodchips and thresholds to classify ranges of values to differentiate woodchip qualities. According to the standard, the features analysed were: classification of the material (described in EN-14961 2011 and EN-15149 2011),

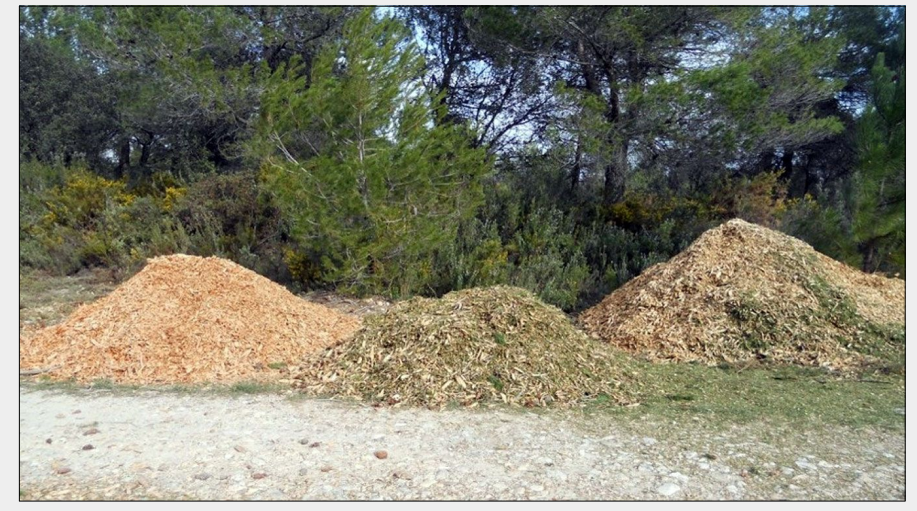

Fig. 1 - Woodchips from WST (left), woodchips from stem (middle) and crown material (right) from IS.

humidity (EN-14774 2010), ash content (EN14775 2010), and calorific value (EN-14918 2011). Three repetitions were made for each woodchip fraction and test (woodchips from stems, from branches and from whole tree).

\section{Calculation of harvesting costs}

Machine rates were calculated based on conventional costing methods (Arnó Satorra \& Vilalta Masip 2003) using personnel and machine costs input from the harvesting company. Tab. 2 shows the machine and labour cost inputs.

\section{Calculation of the net energy efficiency}

of each bioenergy system

The final task of the study was to compare the net energy efficiency of the two bioenergy systems, including all the activities in the supply chain, from transport and logistics operations to the final thermal en- ergy conversion of the woodchips at the bioenergy plant. To this purpose, Hohle (2010) formulas were applied. This methodology allowed a quantitative comparison between the energy input required to carry out the forest operations and the obtained energy output through the transformation of biomass in a thermal combustion plant of $700 \mathrm{kWh}$ per tonne of woodchips. Nevertheless, the energy consumed through the life cycle of machines, fossil fuel (extraction and refinery), and human work were not included in the calculations.

\section{Results and discussion}

\section{Homogeneity of forest plots}

According to ANOVA results, no significant differences were found between DBH and tree volume distribution among plots ( $\mathrm{p}$-value $=0.23$ and $\mathrm{p}$-value $=0.14$, respectively) in both treatments.

Tab. 2 - Machine and labour cost inputs for cost calculations. Cost in Euro $(\epsilon)$ as on April 27, 2021 ( $1 €=1.21$ US). (SMH): scheduled machine hours, inclusive of delays; (*): incidence of work time over total work site time: the remaining time is represented by delays. The utilization rates, investment costs, overheads and industrial benefits were provided by forest operators (Moixent Forestal s.l., 2013).

\begin{tabular}{|c|c|c|c|c|c|}
\hline Costs & Unit & Chainsaw & Forwarder & Chipper & Truck \\
\hline Investment & $€$ & 490 & 130000 & 240000 & 81000 \\
\hline Service life & years & 6 & 10 & 12 & 15 \\
\hline Resale & $€$ & 98 & 26000 & 48000 & 16200 \\
\hline Utilization* & SMH year-1 & 1000 & 1000 & 1500 & 1500 \\
\hline Repairs & $€$ & 41 & 5200 & 8000 & 1512 \\
\hline Depreciation & $€$ year $^{-1}$ & 82 & 10400 & 16000 & 4320 \\
\hline $\begin{array}{l}\text { Average value of year } \\
\text { investment }\end{array}$ & $€$ year $^{-1}$ & 286 & 83200 & 152000 & 50760 \\
\hline Interests & $\%$ & 0 & 0 & 0 & 0 \\
\hline Insurance & $€$ year $^{-1}$ & 2500 & 2500 & 2500 & 2500 \\
\hline Interest & $€$ year $^{-1}$ & 14 & 4160 & 7600 & 2538 \\
\hline Fuel & $€$ year $^{-1}$ & 1250 & 4431 & 30210 & 45315 \\
\hline Lubricants & $€$ year $^{-1}$ & 375 & 1329 & 9063 & 13595 \\
\hline Labour & $€ \mathrm{SMH}^{-1}$ & 20 & 18 & 18 & 18 \\
\hline Crew & $\mathrm{n}$ & 1 & 1 & 1 & 1 \\
\hline Overheads & $€ \mathrm{SMH}^{-1}$ & 2 & 4 & 6 & 5 \\
\hline Total rate & $€ \mathrm{SMH}^{-1}$ & 25 & 53 & 79 & 73 \\
\hline
\end{tabular}


Tab. 3 - Time consumption (min) of harvesting operations per plot and harvesting system. (SD): standard deviation; (CV): coefficient of variation. $\left({ }^{*}\right)$ : assuming $35 \%$ of delays.

\begin{tabular}{|c|c|c|c|c|c|c|c|c|c|c|c|c|c|}
\hline \multirow{2}{*}{ Step } & \multirow{2}{*}{ Operation } & \multicolumn{6}{|l|}{ WTS } & \multicolumn{6}{|l|}{ IS } \\
\hline & & Plot1 & Plot2 & Plot3 & Mean & SD & CV(\%) & Plot4 & Plot5 & Plot6 & Mean & SD & CV(\%) \\
\hline \multirow[t]{4}{*}{ Felling } & Felling & 133.83 & 137 & 85.5 & 118.78 & 28.86 & 24.29 & 217.8 & 188 & 226.16 & 210.65 & 20.05 & 9.52 \\
\hline & Fuel and oil recharge & 18 & 20 & 10.3 & 16.1 & 5.12 & 31.81 & 30.53 & 23.5 & 35.5 & 29.84 & 6.03 & 20.2 \\
\hline & Total & 151.83 & 157 & 95.8 & 134.88 & 33.94 & 25.16 & 248.33 & 211.5 & 261.66 & 240.5 & 25.98 & 10.8 \\
\hline & Time per tree & 1.53 & 1.67 & 1.15 & 1.45 & 0.27 & 18.4 & 2.12 & 2.38 & 3.08 & 2.53 & 0.5 & 19.6 \\
\hline \multirow[t]{8}{*}{ Forwarding } & $\mathrm{n}^{\circ}$ cycles & 4 & 4 & 4 & 4 & 0 & 0 & 2 & 3 & 3 & 2.7 & 0.58 & 21.38 \\
\hline & Distance (m) & 800 & 700 & 700 & 733 & 57.74 & 7.88 & 850 & 750 & 750 & 783 & 57.74 & 7.37 \\
\hline & Loading & 213.16 & 192.63 & 197.9 & 201.23 & 10.66 & 5.3 & 105 & 174.9 & 188.54 & 156.15 & 44.82 & 28.7 \\
\hline & Transp. Loaded & 36 & 33.4 & 28.5 & 32.63 & 3.81 & 11.67 & 20 & 28.5 & 24.33 & 24.28 & 4.25 & 17.51 \\
\hline & Unloading & 33.06 & 30.06 & 43.5 & 35.54 & 7.05 & 19.85 & 23 & 34.9 & 38.32 & 32.07 & 8.04 & 25.08 \\
\hline & Transp. Unloaded & 27.77 & 27.32 & 19 & 24.7 & 4.94 & 19.99 & 17 & 19.5 & 17.32 & 17.94 & 1.36 & 7.58 \\
\hline & Net & 309.99 & 283.41 & 288.9 & 294.1 & 14.03 & 4.77 & 165 & 257.8 & 268.51 & 230.44 & 56.92 & 24.7 \\
\hline & Gross* & 418.49 & 382.6 & 390.02 & 397.04 & 18.95 & 4.77 & 222.75 & 348.03 & 362.49 & 311.09 & 76.85 & 24.7 \\
\hline Chipping & - & 20.5 & 20.6 & 19 & 20.03 & 0.9 & 4.47 & 21.3 & 24.9 & 19.5 & 21.9 & 2.75 & 12.56 \\
\hline
\end{tabular}

\section{Time consumption}

\section{Felling}

Tab. 3 shows the main results of felling time and productivity per harvesting system. WTS showed a lower average time consumption than IS (119 vs. 211 min plot $^{-1}$ ), since the latter required an extra time for delimbing and crown cutting. Regarding fuel and oil recharge, this accounted for the same percentage (12\%) in both systems, totaling 16.10 and $29.84 \mathrm{~min}$ plot $^{-1}$ in the WTS and the IS systems, respectively.

\section{Forwarding}

Tab. 3 shows the time consumption per plot and harvesting system for the forwarding operation. Total average loading time was 156 min plot $^{-1}$ for IS and $201 \mathrm{~min}$ plot $^{-1}$ for WTS. The number of forwarding cycles from the stump to the loading area

Tab. 4 - Comparisons of biomass yield per forest plot and harvesting system. (SD): standard deviation; (CV): coefficient of variation.

\begin{tabular}{|c|c|c|}
\hline System & Test plot & 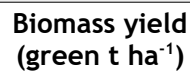 \\
\hline \multirow[t]{6}{*}{ WTS } & Plot1 & 24.27 \\
\hline & Plot2 & 24.46 \\
\hline & Plot3 & 22.56 \\
\hline & Mean & 23.76 \\
\hline & $S D$ & 1.05 \\
\hline & $C V(\%)$ & 4.40 \\
\hline \multirow[t]{6}{*}{ IS } & Plot4 & 29.04 \\
\hline & Plot5 & 23.50 \\
\hline & Plot6 & 27.44 \\
\hline & Mean & 26.66 \\
\hline & $S D$ & 2.85 \\
\hline & $C V(\%)$ & 10.69 \\
\hline
\end{tabular}

was greater for WTS, with an average of 4 cycles plot ${ }^{-1}$ vs. 3 cycles plot ${ }^{-1}$ in the case of IS in which residues and stems were forwarded separately. The results revealed that the net payload of the forwarder was reduced by the bigger volume occupied by the whole trees. Tolosana et al. (2013) reported similar results with a Timberjack 1410 and a Dingo forwarder, demonstrating that tree volume is the critical factor when forwarding whole trees.

The average time of transport loaded was quite similar, i.e., $33 \mathrm{~min}$ for the WTS and $24 \mathrm{~min}$ for the IS. This differences could be explained by a speed reduction of $5.36 \%$, with $90 \mathrm{~m} \mathrm{~min}^{-1}$ in the case of WTS and 85 $\mathrm{m} \mathrm{min}^{-1}$ in the case of IS, which transported bigger loads per cycle. Unloading time was very similar, with an average of $36 \mathrm{~min}$ and 32 min for WTS and IS, respectively. Finally, there was a non-significant difference in the total time per plot associated with transport unloaded. Despite the similar speed, this occurred because WTS required more transport cycles per plot than the IS system.

\section{Chipping}

Tab. 3 shows the results for chipping operations. On average, the chipping of the biomass took $20 \mathrm{~min}$ for the WTS and 22 min for the two piles obtained with IS system.

\section{Biomass yield and fuel consumption}

Tab. 4 shows the biomass yield of the two analysed systems. The average value of green biomass yield for WTS (23.76 $\left.\mathrm{t} \mathrm{ha}^{-1}\right)$ was slightly lower than for IS (26.66 $\left.\mathrm{t} \mathrm{ha}^{-1}\right)$. The quantity of extracted biomass was not the same due to slight differences in diameter and height of the felled trees. Nevertheless, the $t$-test analysis showed no significant differences ( $p$-value $=0.21)$. This confirmed that the same thinning intensity was implemented in all forest plots and harvesting system, allowing an accurate comparison of the variables analysed in this study.

Fig. 2 shows the fuel consumption of the two harvesting systems. On average, fuel was recharged 8.4 times in IS, with an average total consumption of 2.12 litres per plot, and 4.3 times in WTS, with an average total consumption of 2.7 litres per plot. Therefore, the average fuel consumption of the chainsaw operation per tonne in IS (0.63 $\mathrm{I} \mathrm{t}^{-1}$ ) almost duplicated that of WTS $\left(0.35 \mathrm{I} \mathrm{t}^{-1}\right)$, being the difference statistically significant ( $p$-value $=0.04)$. This can be explained by the further processing time involved in IS with delimbing. As for the forwarder, the obtained fuel consumption of the two systems (2.59 and $3.65 \mathrm{I} \mathrm{t}^{-1}$ for IS and WTS, respectively) was not significantly different $(p$-value $=0.13)$. Also, the fuel consumption of the chipper was similar in both systems $\left(1.21 \mid t^{-1}\right.$ for IS and $\left.1.12\right|^{-1}$ for WTS) and no significant differences were found ( $p$-value $=0.32$ ). As for total fuel consumption, WTS consumed $5.12 \mathrm{I} \mathrm{t}^{-1}$ in contrast to $4.43 \mathrm{I} \mathrm{t}^{-1}$ of IS. These results confirmed that chainsaw fuel consumption is the factor underlying the significant differences in fuel consumption between harvesting systems.

\section{Productivity}

Tab. 5 shows a summary of the productivities by plot and operation for the two harvesting systems under study.

\section{Felling}

The average felling productivity of WTS exceeded that of IS (2.76vs. $1.66 \mathrm{t} \mathrm{h}^{-1}$, respectively; $t$-test $p$-value $=0.04$ ) as the latter required additional wood processing (delimbing) time. Furthermore, the felling productivity obtained for IS $\left(2.5 \mathrm{~m}^{3} \mathrm{~h}^{-1}\right.$ for a green density of $0.668 \mathrm{t} \mathrm{m}^{3}$ at $35 \%$ moisture content) was similar to that obtained by Ambrosio (2005), who reported a felling 
productivity of $2.7 \mathrm{~m}^{3} \mathrm{~h}^{-1}$ for a manual selective thinning on a similar stand of Pinus sylvestris in northern Spain. Spinelli et al. (2014) also found significant differences between the WT and CTL harvesting systems.

\section{Forwarding}

On average of 4 trips and 294 min were required by the forwarder to move for forwarding 5.94 tonnes of biomass in WTS, whereas 2.7 trips and $230 \mathrm{~min}$ were required by the forwarder to move 6.66 tonnes in IS. Therefore, the productivity of the forwarding operation in IS was $52 \%$ higher than in WTS (1.85 vs. $\left.1.21 \mathrm{t} \mathrm{h}^{-1}\right)$. Nevertheless, we found no significant difference between treatments after $t$-test $(p=$ 0.18 ). The higher forwarding productivity of IS was previously highlighted by Heikkilä et al. (2006), who reported a higher productivity when forwarding delimbed logs and stems (10-20\% higher) than forwarding whole trees. This is mainly due to the bigger apparent volume occupied by the branches in whole trees loads compared with separated loads of logs and logging residues.

The low productivity rates calculated in our study differed from those reported by Tolosana et al. (2013), who obtained $10.2 \mathrm{t}$ $\mathrm{h}^{-1}$ for the Timberjack and $3.2 \mathrm{t} \mathrm{h}^{-1}$ for the Dingo in IS. In their study, the forwarders worked systematically extracting logs to forest tracks and aligning forest residues from crowns and branches. In our research the forwarder moved selectively from one tree to another. A systematic alignment resulted in a substantial increase in the forwarding productivity of IS. Additionally, Nurmi \& Hillebrand (2007) reported that forwarder capacity, distance to loading area, weight and quantity of biomass per hectare are key factors for the productivity in the forwarding operation. Based on our experience, felling and forwarding productivities increase with larger harvested areas and higher biomass yields per hectare.

\section{Chipping}

Regarding chipping productivity, the forest company only provided the total time spent by the chipping operation in each system. From this data, the calculated net productivity was $17.79 \mathrm{t} \mathrm{h}^{-1}$ for WTS and $16.55 \mathrm{t} \mathrm{h}^{-1}$ for IS. This is mainly due to the fact that in the case of IS, the chipper does not have to move from one pile (woodchips from stems) to another (woodchips from forest residues) during the chipping operation. Tolosana et al. (2013) obtained a similar productivity $\left(14 \mathrm{t} \mathrm{h}^{-1}\right)$ in a chipping operation on residues of Pinus sylvestris (branches and tops piled up in the landing area).

\section{Biomass quality}

In our study, biomass quality highly depended on the fraction of the three piles obtained and analysed after the chipping operation (Fig. 1). Tab. 6 shows the results obtained in the laboratory for particle size,

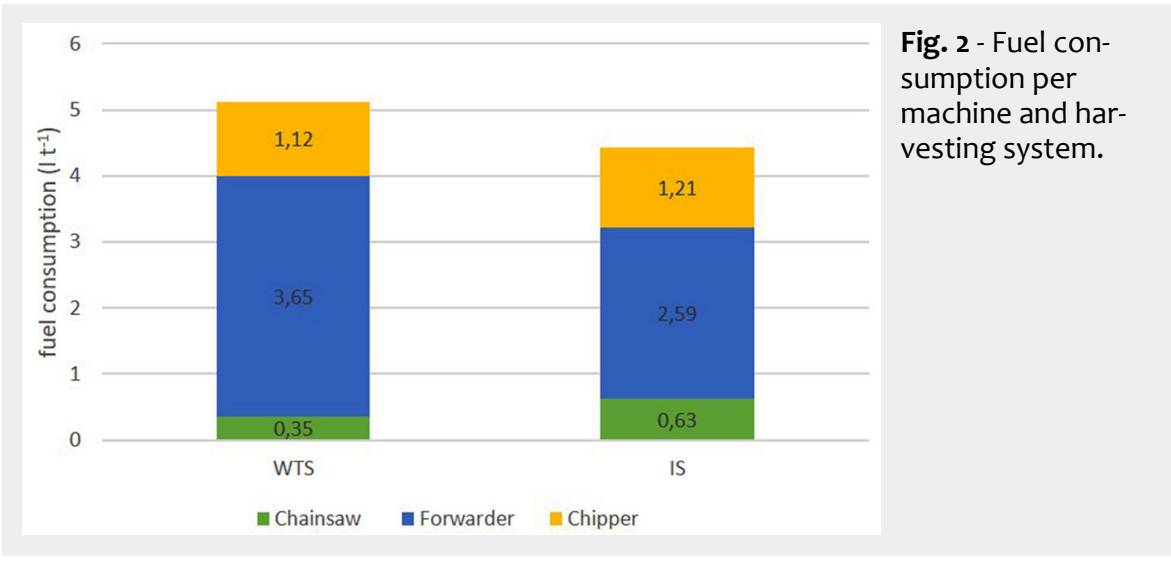

moisture, ash content and net calorific line with those reported by Spinelli et al. value, as well as their assigned quality (2014) who indicated that WT harvesting classes following standard EN-14961 (2011). produces whole-tree chips which contain a The woodchips obtained from WTS were larger proportion of needles and twigs rated as EN PLUS B1, while IS supplied two compared to the chips obtained from CTL different qualities: EN PLUS A2 for log chips harvesting. Nevertheless, they are suitable (if dried up to $35 \%$ moisture content). The for use in small-scale residential heating rest of woodchips from logging residues systems.

did not pass the EN quality tests due to the Regional market prices for the different high content of ashes. These results are in woodchip quality assortments determine

Tab. 5 - Comparisons of productivity and costs of the two harvesting systems. $(P)$ : productivity; (Av. P): average productivity; (Hc): hourly cost; (EWT): effective working time; (Uc): unit cost; (SD): standard deviation; (CV): coefficient of variation; (*): as result of fixed and variable cost plus industrial profit and overheads (calculated as $6 \%$ and $8 \%$ of hourly operating costs, respectively, according to forest operators).

\begin{tabular}{|c|c|c|c|c|c|c|c|}
\hline System & Operation & $\begin{array}{l}\text { Plot/ } \\
\text { Stats }\end{array}$ & $\begin{array}{c}P \\
\left(\mathrm{t} \mathrm{h}^{-1}\right)\end{array}$ & $\begin{array}{l}\text { Av. P } \\
\left(\mathrm{t} \mathrm{h}^{-1}\right)\end{array}$ & $\begin{array}{c}\mathrm{Hc} \\
\left(€ \mathrm{~h}^{-1}\right)^{*}\end{array}$ & $\begin{array}{c}\text { EWT } \\
\left(\mathrm{h} \mathrm{t}^{-1}\right)\end{array}$ & $\begin{array}{c}U c \\
\left(€ t^{-1}\right)\end{array}$ \\
\hline \multirow[t]{13}{*}{ WTS } & \multirow[t]{5}{*}{ Felling } & Plot1 & 2.4 & \multirow[t]{3}{*}{2.76} & \multirow[t]{3}{*}{25} & \multirow[t]{3}{*}{0.36} & \multirow[t]{3}{*}{9.06} \\
\hline & & Plot2 & 2.34 & & & & \\
\hline & & Plot3 & 3.53 & & & & \\
\hline & & $S D$ & 0.67 & - & - & - & - \\
\hline & & $C V(\%)$ & 24.44 & - & - & - & - \\
\hline & \multirow[t]{5}{*}{ Forwarding } & Plot1 & 1.17 & \multirow[t]{3}{*}{1.21} & \multirow[t]{3}{*}{53} & \multirow[t]{3}{*}{0.83} & \multirow[t]{3}{*}{43.73} \\
\hline & & Plot2 & 1.29 & & & & \\
\hline & & Plot3 & 1.17 & & & & \\
\hline & & $S D$ & 0.07 & - & - & - & - \\
\hline & & $C V(\%)$ & 5.79 & - & - & - & - \\
\hline & Chipping & - & 17.79 & 17.79 & 79 & 0.06 & 4.44 \\
\hline & Transport & - & 22 & 22 & 73 & 0.05 & 3.32 \\
\hline & Total & - & - & - & - & - & 60.56 \\
\hline \multirow[t]{13}{*}{ IS } & \multirow[t]{5}{*}{ Felling } & Plot4 & 1.75 & \multirow[t]{3}{*}{1.66} & \multirow[t]{3}{*}{25} & \multirow[t]{3}{*}{0.6} & \multirow[t]{3}{*}{14.98} \\
\hline & & Plot5 & 1.67 & & & & \\
\hline & & Plot6 & 1.57 & & & & \\
\hline & & $S D$ & 0.07 & - & - & - & - \\
\hline & & $C V(\%)$ & 5.79 & - & - & - & - \\
\hline & \multirow[t]{5}{*}{ Forwarding } & Plot4 & 2.64 & \multirow[t]{3}{*}{1.85} & \multirow[t]{3}{*}{53} & \multirow[t]{3}{*}{0.54} & \multirow[t]{3}{*}{28.87} \\
\hline & & Plot5 & 1.37 & & & & \\
\hline & & Plot6 & 1.53 & & & & \\
\hline & & $S D$ & 0.67 & - & - & - & - \\
\hline & & $C V(\%)$ & 37.47 & - & - & - & - \\
\hline & Chipping & - & 16.55 & 16.55 & 79 & 0.06 & 4.77 \\
\hline & Transport & - & 22 & 22 & 73 & 0.05 & 3.33 \\
\hline & Total & - & - & - & - & - & 51.93 \\
\hline
\end{tabular}


Tab. 6 - Comparisons of biomass quality of woodchips obtained from the two harvesting systems. (o.d.): oven-dried.

\begin{tabular}{lccc}
\hline Characteristics & WTS & \multicolumn{2}{c}{ IS } \\
\hline Origin of chips sample & Whole tree & Stem & Branches \\
\hline Particle size (mm, EN-15149 2011) & P31.5 & P31.5 & P31.5 \\
\hline Moisture content (\% o.d. weight, EN-14774 2010) & 41 & 45.18 & 38.13 \\
\hline Ash content (\% o.d. weight, EN-14775 2010) & 2 & 1.09 & 3.24 \\
\hline Net calorific value (MJ kg-1 ${ }^{-1}$ EN-14918 2011) & 17.53 & 17.59 & 17.27 \\
\hline Quality (EN-14961 2011) & ENPLUS B1 & ENPLUS A2 & - \\
\hline
\end{tabular}

the convenience of one system over the other. Generally, obtaining two qualities of woodchips as in IS might result in higher revenues and this would justify the processing (delimbing) of the logs and the separate piling and chipping performed in IS.

\section{Costs}

Tab. 5 shows the cost summary for the two harvesting systems. Assuming a transport with a multi-lift truck from the forest landing area to a bioenergy plant located $40 \mathrm{~km}$ away, the unit cost for WTS (60.56 $€$ $\mathrm{t}^{-1}$ at $45 \%$ biomass moisture content, hereafter: MC) was slightly higher than for IS ( $51.93 € \mathrm{t}^{-1}$ at $45 \%$ biomass MC). These costs amounted to $110.10 € \mathrm{t}^{-1}$ for the WTS and $94.42 € \mathrm{t}^{-1}$ for the IS at $0 \%$ of biomass MC. Using the wood calorific values calculated for Pinus halepensis, average costs per energy unit bases were 22.61 and $19.39 €$ $M \mathrm{Mh}^{-1}$ for WTS and IS, respectively.

These results are in line with those reported by ENERSILVA (2007) for several Mediterranean pine species (41-95 $€ \mathrm{t}^{-1}$ at $26 \% M C$ ). For the same $M C$ our results were $95 € \mathrm{t}^{-1}$ for WTS and $65 € \mathrm{t}^{-1}$ for IS. In contrast, the cost obtained were clearly higher than those presented in a previous study by Frühwald (2007) where the cost of woodchips from biomass residues were lower than the costs from whole tree harvesting for Picea abies in Scandinavia and Northern Germany (10 $€ \mathrm{MWh}^{-1}$ and $15 €$ $\mathrm{MWh}^{-1}$, respectively). The net calorific value of the biomass from Mediterranean pinewood was slightly higher than that of softwoods from Central and Northern Europe (Lerma-Arce et al. 2017). However, selective thinnings oriented to fire prevention in stands with low stocking volume and significant terrain slopes cannot compete from a pure economic point of view with selective thinnings of spruce or Scots pine forests on flat lands in Central and Northern Europe. Thus, both the productivity and cost of the wood and harvesting sys tem are determined by forest stand and harvesting variables such as tree sizes, harvesting intensity, forwarding distance, and operators qualities (LeDoux \& Huyler 2001). Tab. 5 shows that the most expensive operations were forwarding followed by manual chainsaw felling. The lower productivity of the forwarding operation in
WTS was compensated by the higher felling productivity. According to Kellogg \& Spong (2004), forwarding was the most expensive activity in both systems, which accounted for $72 \%$ and $57 \%$ of the total costs in WTS and IS, respectively. These results are consistent with those presented by Adebayo et al. (2007) who reported that $54 \%$ and $36 \%$ of the costs were attributed to the forwarding operation in WTS and IS, respectively, with the difference that in this study the felling was mechanized. Differences in total costs between WTS and IS keep constant of $20 \%$ for both the above studies (Kellogg \& Spong 2004, Adebayo et al. 2007). It must be considered that with bigger forwarders these costs could be reduced, although potential environmental impact (damages to soil and remaining vegetation) might occur. Additional systematic operations like piling of forest residues and alignment of logs or whole trees along forest tracks could increase forwarding productivities and reduce costs. Moreover, it has to be considered that costs may vary considerably from company to company, and experimental trials are normally more cost-intensive than real working operations.

\section{Net energy efficiency}

We conducted a comparative analysis of the net energy efficiency along the entire supply chain, from the forest to the thermal energy conversion of the obtained woodchips. The analysis included all fossil fuels consumed by the harvesting, chipping and transport equipment. The input to output energy rate was $9.3 \%$ for the WTS and $8.3 \%$ for the IS. A total of 10.7 and 12.0 of units of equivalent biomass energy were produced from every unit of energy input of fossil fuel required to mobilise and transform the biomass for WTS and IS, respectively. These results agree with those reported in the ForBioEnergy (2019) project, which included several pine studies in Spain, Italy, Slovenia and Croatia. The lower value of bioenergy units produced in WTS was due to the higher energy consumption of the forwarding operation. This highlights that is critical to optimize such process to increase the net energy efficiency of the supply chain (Yoshioka 2011). Results were determined by the size and capacity of the reference combustion plant and were in line with Wihersaari (2005) who obtained 30 to 50 units of bioenergy produced for every unit of (fossil) energy consumed from fuel chips from logging residues at final harvest. In another study, Valente et al. (2011) reported that WTS can produce 20 units of bioenergy per fossil fuel energy unit. The higher values reported by the mentioned studies show a potential improvement in energy efficiency that probably could be achieved by including larger harvesting areas and optimizing the logistics operations.

\section{Conclusions}

Biomass yield and fuel consumption were similar between WTS and IS harvesting system, while time differences are due to the higher processing time that IS requires during the felling operation, and to the lower forwarding capacity per cycle in WTS caused by the higher apparent volume of whole trees in comparison with the separate forwarding of stems and residues in IS. The felling productivity of WTS was higher than that of IS. Nevertheless, the forwarding productivity of WTS was lower than that of IS. No significant differences were found for the biomass chipping from both systems. Both harvesting systems yielded woodchip of quality complying with non-industrial EN standards. Total harvesting costs were slightly higher in WTS due to the more intensive forwarding operations.

Both harvesting systems produce woodchips whose energy is tenfold higher than that required to mobilise and process the harvested biomass. This implies a high potential for the substitution of non-renewable fossil fuels by wood-based biofuels. Nevertheless, further investigations including life-cycle analyses of biofuels is needed to confirm this issue.

After the evaluation of the productivity, fuel consumption, and energy efficiency of WTS and IS, we conclude that IS is the most productive, economic and environmental effective harvesting system for the harvesting of pole stage stands of afforested Pinus halepensis. Nevertheless, both systems are highly sensitive to machine productivity and forest stand variables.

\section{Acknowledgements}

VLA and JVOV conceived the study and draft the manuscript; VLA carried out the field measurements; VLA and GSO carried out the biomass tests in the laboratory; VLA, JVOV and JFUS performed the statistical analysis.

This work was partially funded by the Government of Valencia (IVACE, Spain) in the framework of the BIOPELLET project. The authors want to acknowledge the support of the forest company Moixent Forestal, the Municipality of Enguera and the AIDIMME Technology Institute and very especially the support of Dr. Raffaele Spinelli for providing methodological support in 
the frame of COST Action FPog02. Finally, a special thank to the reviewers who improved and enriched the publication with their valuable contributions.

\section{References}

Acuna M, Sessions J, Zamora-Cristales R, Boston K, Brown M, Ghaffariyan M (2019). Methods to manage and optimize forest biomass supply chains: a review. Current Forestry Reports 5 (3): 124-141. - doi: 10.1007/s40725-019-00093-4 Adebayo AB, Han HS, Johnson L (2007). Productivity and cost of cut-to-length and whole-tree harvesting in a mixed-conifer stand. Forest Products Journal 57: 59-69.

Ambrosio Y (2005). Estudios de tiempos de cosechadoras forestales en una seria de aprovechamientos de primera clara en masas de $\mathrm{Pi}$ nus radiata y Pinus sylvestris en el distrito forestal VII de Galicia [Timing studies of forest harvesters in a series of first thinnings in Pinus radiata and Pinus sylvestris stands in Forest District VII of Galicia]. In: Proceedings of the "Congreso Forestal de Portugal 2005", Lisboa (Portugal) 16-19 May 2005. Sociedade Portuguesa de Ciências Florestais, Viseu, Portugal, pp. 8. [in Spanish]

Ambrosio Y, Tolosana E (2007). El control de tiempos y rendimientos en los trabajos forestales. El programa Kronos [The control of times and yields in forestry work. The Kronos program]. Revista Montes 87: 14-20. [in Spanish]

Arnó Satorra J, Vilalta Masip J (2003). Cost horari de la maquinària forestal [Hourly cost of the forest machinery]. Institut d'Edicions de la Diputació de Barcelona, Xarxa de Municipis, Àrea d'Infraestructures, Urbanisme i Habitatge, Oficina Tècnica de Prevenció Municipal d'Incendis Forestals Quaderns d'Informació Tècnica, Barcelona, Spain, pp. 95. [in Catalan]

Balboa M, Alvarez J, Rodriguez-Soalleiro R, Merino A (2003). Aprovechamiento de la biomasa forestal producida por la cadena monteindustria. Parte II: Cuantificación e implicaciones ambientales [Use of forest biomass produced by the forest-industry chain. Part II: Quantification and environmental implications]. CIS-Madera 10: 27-37. [in Spanish]

Barbati A, Arianoutsou M, Corona P, De Las Heras J, Fernandes P, Moreira F, Papageorgiou K, Vallejo R, Xanthopoulos G (2010). Post-fire forest management in southern Europe: a COST action for gathering and disseminating scientific knowledge. iForest - Biogeosciences and Forestry 3 (1): 5-7. - doi: 10.3832/iforo523003

BEST4VARIOUSE (2012). Best practices and technologies to develop green wastes and residues as raw materials for variants of utilization. LIFE07 ENV/D/000240 Layman report, European Commission, Brussels, Belgium, pp. 15.

EN-14774 (2010). Solid biofuels - Determination of moisture content - Oven dry method. Asociación Española de Normalización y Certificación, Madrid, Spain, pp. 33.

EN-14775 (2010). Solid biofuels - Determination of ash content. Asociación Española de Normalización y Certificación, Madrid, Spain, pp. 12.

EN-14918 (2011). Solid biofuels - Determination of calorific value. Asociación Española de Normal- ización y Certificación, Madrid, Spain, pp. 61. EN-14961 (2011). Solid biofuels - Fuel specifications and classes - Part 1: General requirements. - Part 4: Wood chips for non-industrial use. Asociación Española de Normalización y Certificación, Madrid, Spain, pp. 116.

EN-15149 (2011). Solid biofuels - Methods for the determination of particle size distribution - Part 1: Oscillating screen method using sieve apertures of $3.15 \mathrm{~mm}$ and above. Asociación Española de Normalización y Certificación, Madrid, Spain, pp. 32.

ENERSILVA (2007). Promoción del uso de la biomasa forestal con fines energéticos en el Suroeste de Europa (2004-2007) [Promotion of the use of forest biomass for energy purposes in Southwest Europe (2004-2007)]. Interreg SUDOE, Final Report 978-972-96003-7-1, Santiago de Compostela, Spain, pp. 44. [in Spanish] European Commission (2020). National renewable energy action plans progress reports (NREAPs Progress reports) from Member States under Article 22 of Directive 2009/28/EC on the promotion of the use of energy from renewable sources. European Commission, Brussels, Belgium. [online] URL: http://ec.europa. eu/energy/en/topics/renewable-energy/progres s-reports

ForBioEnergy (2019). Forest bioenergy in the protected Mediterranean areas - ForBioEnergy. Final Report, Interreg MED Project ForBioEnergy, Palermo, Italy, pp. 240.

Frühwald A (2007). Technologies and economics of energy generation from logging residues and wood processing waste. In: Proceedings of the "International Conference on Wood-based Bioenergy", Hannover (Germany) 17-18 May 2007, pp. 34. [online] URL: http://www.itto.int/ direct/topics/topics_pdf_download/topics_id=3 2920000\&no $=91$

Goubitz S, Werger MJA, Shmida A, Neeman G (2002). Cone abortion in Pinus halepensis Mill.: the role of pollen quantity, tree size and cone location. Oikos 97 (1): 125-133. - doi: 10.1034/j.16 00-0706.2002.970113.x

Heikkilä J, Laitila J, Tanttu V, Jari Lindblad J, Sirén M, Asikainen A (2006). Harvesting alternatives and cost factors of delimbed energy wood. Forestry Studies. Metsanduslikud Uurimused 45: 49-56.

Hohle AME (2010). Energy consumption by energy wood supply. In: Proceedings of the "OSCAR Conference in Forest Operation Research in the Nordic Baltic Region". Honne (Norway) 20-22 Oct 2010. Norsk Institutt for Skog og Landskap, Norway, pp. 100.

Jaouadi W, Naghmouchi S, Alsubeie M (2019). Should the silviculture of Aleppo pine (Pinus halepensis Mill.) stands in northern Africa be oriented towards wood or seed and cone production? Diagnosis and current potentiality. iForest - Biogeosciences and Forestry 12 (3): 297-305. - doi: 10.3832/ifor2965-012

Joelsson J, Di Fulvio F, De La Fuente T, Bergström D, Athanassiadis D (2016). Integrated supply of stemwood and residual biomass to forest-based biorefineries. International Journal of Forest Engineering 27 (2): 115-138. - doi: 10.1080/14942119.2016.1184955

Kellogg LD, Spong B (2004). Production and costs of cut-to-length thinning: experience from the Willamette young stand project. Forest Research Laboratory, Oregon State University, Corvallis, OR, USA, pp. 23.

Lavi A, Kigel J, Noy-Meir I (2005). Invasion of Pinus halepensis from plantations into adjacent natural habitats. Applied Vegetation Science 8 (1): 85-92. - doi: 10.1111/j.1654-109X.2005.tboo63 2.x

LeDoux CB, Huyler NK (2001). Comparison of two cut-to-length harvesting systems operating in eastern hardwoods. International Journal of Forest Engineering 12 (1): 53-59.

Lerma-Arce V (2015). Planificación, logística y valorización de biomasa forestal residual en la provincia de Valencia [Planning, logistics and recovery of residual forest biomass in the province of Valencia]. PhD Thesis, Universitat Politècnica de València, Spain, pp. 230. [in Spanish]

Lerma-Arce V, Oliver-Villanueva JV, SeguraOrenga G (2017). Influence of raw material composition of Mediterranean pinewood on pellet quality. Biomass and Bioenergy 99: 9096. - doi: 10.1016/j.biombioe.2017.02.018

Maestre F, Cortina J (2004). Are Pinus halepensis plantations useful as a restoration tool in semiarid Mediterranean areas? Forest Ecology and Management 198 (1-3): 303-317. - doi: 10.1016/j. forec0.2004.05.040

Magagnotti N, Spinelli R (2012). Good practice guidelines for biomass production studies. COST Action FP-0902, WG2 "Operations Research and Measurement Methodologies", CNR-IVALSA, Sesto Fiorentino, FI, Italy, pp. 52.

Montero G, Ruiz-Peinado R, Muñoz M (2005). Producción de biomasa y fijación de $\mathrm{CO}_{2}$ por los bosques españoles [Biomass production and $\mathrm{CO}_{2}$ fixation by Spanish forests]. Monografías INIA, Serie Forestal no. 13, Madrid, Spain, pp. 270. [in Spanish]

Moya D, De Las Heras J, Lopez-Serrano FR, Leone $V$ (2008). Optimal intensity and age management in young Aleppo pine stands for post-fire resilience. Forest Ecology and Management 255 (8-9): 3270-3280.

Navarro FB, Jimenez MN, Cañadas EM, Gallego E, Terrón L, Ripoll MA (2010). Effects of different intensities of overstory thinning on tree growth and understory plant-species productivity in a semi-arid Pinus halepensis Mill. afforestation. Forest Systems 19 (3): 410-417. doi: $10.5424 /$ fs/2010193-8858

Nurmi J, Hillebrand K (2007). The characteristics of whole-tree fuel stocks from silvicultural cleanings and thinnings, Biomass and Bioenergy 31: 381-392. - doi: 10.1016/j.biombioe.2007. 01.010

PATFOR (2012). Plan de acción territorial forestal de la comunidad Valenciana [Forest territorial action plan of the Valencian community]. VAERSA, Conselleria d'Infraestructures, Territori i Medi Ambient, Valencia, Spain, pp. 860. [in Spanish]

Pecchi M, Marchi M, Giannetti F, Bernetti I, Bindi M, Moriondo M, Maselli F, Fibbi L, Corona P, Travaglini D, Chirici G (2019). Reviewing climatic traits for the main forest tree species in Italy. iForest - Biogeosciences and Forestry 12 (2): 173-180. - doi: 10.3832/ifor2835-012

PROFORBIOMED (2014). Promotion of residual forestry biomass in the Mediterranean basin. 
Final Project Report, INTERREG MED 1S-MED 10-009, Murcia, Spain, pp. 252.

Proskurina S, Sikkema R, Heinimö J, Vakkilainen EK (2016). Five years left - How are the EU member states contributing to the $20 \%$ target for EU's renewable energy consumption; the role of woody biomass. Biomass and Bioenergy 95: 64-77. - doi: 10.1016/j.biombioe.2016.09.016 Rauch P, Wolfsmayr UJ, Borz SA, Triplat M, Krajnc $N$, Kolck $M$, Oberwimmer R, Ketikidis $C$, Vasiljevic A, Stauder M, Mühlberg C, Derczeni R, Oravec M, Krissakova I, Handlos M (2015). SWOT analysis and strategy development for forest supply chains in South East Europe. Forest Policy and Economics 61: 87-94. - doi: 10.1016/j.forpol.2015.09.003

Scarlat N, Dallemand J, Taylor N, Banja M (2019). Brief on biomass for energy in the European Union (Sanchez Lopez J, Avraamides M eds). JRC109354, Publications Office of the European Union, Luxembourg, pp. 8. - doi: 10.2760/5469 43

Schweier J, Spinelli R, Magagnotti N, Becker G (2015). Mechanized coppice harvesting with new small-scale feller-bunchers: results from harvesting trials with newly manufactured felling heads in Italy. Biomass and Bioenergy 72: 85-94. - doi: 10.1016/j.biombioe.2014.11.013
Sghaier T, Ammari Y (2012). Croissance et production du pin d'Alep (Pinus halepensis Mill.) en Tunisie [Growth and production of Aleppo pine (Pinus halepensis Mill.) in Tunisia]. Ecologia Mediterranea 38 (1): 39-57. [in French] - doi: 10.3406/ecmed.2012.1325

Spinelli R, Lombardini C, Magagnotti N (2014). The effect of mechanization level and harvesting system on the thinning cost of Mediterranean softwood plantations. Silva Fennica 48 (1): 15.

Spinelli R, Visser R, Björheden R, Röser D (2019). Recovering energy biomass in conventional forest operations: a review of integrated harvesting systems. Current Forestry Reports 5: 90100. - doi: 10.1007/s40725-019-00089-0

Tolosana E, Laina Relaño R, Martínez Ferrari R, Ambrosio Torrijos $Y$ (2013). El aprovechamiento de biomasa residual (ramas y copas) en cortas a hecho de coníferas en Soria (España) [The use of residual biomass (branches and tops) in conifers clear-cuttings in Soria (Spain)]. In: Proceedings of the " 6 a Congreso Forestal Español: Montes: Servicios y Desarrollo Rural". VitoriaGasteiz (Spain) 10-14 June 2013. Sociedad Española de Ciencias Forestales, 6CFE01-520, Palencia, Spain, pp. 12. [in Spanish]

Triplat M, Krajnc N (2020). Assessment of costs in harvesting systems using WoodChainManager web-based tool. Croatian Journal of Forest Engineering 41 (1): 9. - doi: 10.5552/crojfe. 2020.583

Valente C, Spinelli R, Hillring BG (2011). LCA of environmental and socio-economic impacts related to wood energy production in alpine conditions. Journal of Cleaner Production 19 (1718): 1931-1938. - doi: 10.1016/j.jclepro.2011.06.0 26

Vennetier M, Ripert C, Brochiéro F, Rathgeber CBK, Chandioux O, Estève R (2010). Evaluation de la croissance du pin d'Alep en région méditerranéenne française [Assessment of the growth of Aleppo pine in the French Mediterranean region]. Revue Forestière Française 5: 11. [in French]

Wihersaari M (2005). Greenhouse gas emissions from final harvest fuel chip production in Finland. Biomass and Bioenergy 28: 435-443. - doi: 10.1016/j.biombioe.2004.11.007

Yoshioka T (2011). Study on the feasibility of a harvesting, transporting, and chipping system for forest biomass resources in Japan. Agri-Bioscience Monographs 1: 1-60. - doi: 10.5047/agb m.2011.00101.0001 